\title{
PROBLEM DAN SOLUSI ATAS PENERAPAN TA'ZIR DI PESANTREN (Studi Kasus di Pondok Pesantren Al Ibrohimy Galis Bangkalan)
}

\section{Mo'tasim'; Zaini Tamin $\mathbf{A R}^{2}$}

STIT Al Ibrohimy Bangkalan ${ }^{1}$; STAI YPBWI Surabaya ${ }^{2}$

Email: billahmutasim73@yahoo.com ${ }^{1}$; zainitamin@stai-ypbwi.ac.id ${ }^{2}$

\author{
Article History: \\ Received: $12-02-2020$ \\ Revised: 15-03-2020 \\ Accepted: 09-03-2020
}

\begin{abstract}
Initially, the application of ta'zir was considered normal among pesantren and the community. But lately, not a few who argue that ta'zir applied in pesantren is synonymous with violence. This study aims to analyze the problem of applying Ta'zir in Al Ibrohimy Galis Bangkalan Islamic boarding school along with alternative solutions that rely on Human Rights in Indonesia. The author uses descriptive qualitative research, with primary data sources Al Ibrohimy boarding school and board chair, as well as relevant secondary sources. Meanwhile, data collection techniques through observation, interviews, documentation and questionnaires. The findings of this study reveal that ta'zir in Al Ibrohimy Islamic boarding school is a way of disciplining troubled students to obey the rules of Islamic boarding schools. The application of ta'zir is also understood as a means of educating students to have a deterrent effect and not to repeat it. However, ta'zir sometimes makes students become depressed, traumatized and even physically and psychologically ill. Therefore, there must be aware of the pesantren that excessive ta'zir is an act that cannot be fully justified. Thus, all elements of pesantren must have ta'zir options that do not conflict with human rights. Besides, to minimize excessive ta'zir, a reconstruction of the system is needed that provides an alternative punishment for education. So that educational activities in boarding schools run dynamically and humanist
\end{abstract}

Keyword : Ta'zir, Islamic Boarding School, Human Rights, Humanist Education

\section{Pendahuluan}

Pesantren memiliki unsur utama yang berbasiskan pada subyek manusia yakni kiai dan santri. Hubungan relasional antara keduanya inilah melahirkan suatu bentukbentuk komunikasi edukatif dalam proses pembelajaran di pesantren. Kiai adalah seorang pengajar pendidik, pengelola, guru (ustadz) dan sekaligus pemangku pesantren. Dan santri sebagai siswa yang belajar kepada sang kiai untuk mendapatkan ilmu. Pada tingkat tertentu, khususnya pesantren salaf masih nampak jelas dalam memposisikan santri sebagai obyek didik yang dapat dibentuk sedemikian rupa. Namun, ini cukup berbeda pada pesantren - pesantren khalaf, di sini santri telah dicoba untuk diposisikan sebagai subyek yang harus aktif dan diposisikan sebagai manusia yang menuntut untuk diperlakukan secara wajar dan demokratis. Dengan kata lain, pesantren memiliki karakteristiknya tersendiri dibanding dengan lembaga - lembaga pendidikan yang ada di 
tanah air. ${ }^{1}$ Sementara itu, santri yang berkategori sebagai anak didik di pondok pesantren ditemukan sejumlah fenomena yang dapat diindikasikan sebagai wujud kekerasan dan pelanggaran terhadap anak. Berbagai bentuk perlakuan telah dapat disaksikan di sejumlah lembaga pendidikan pondok pesantren. Sumber potensial sebagai subyek pelaku kekerasan bisa meliputi; Kiai, pemangku pondok, pengelola pondok, pengurus pondok, pembinan pondok, sejumlah penerapan aturan - aturan yang mengekang secara sepihak dan lain sebagainya.

Tindak kekerasan tersebut nampaknya belum disadari sepenuhnya oleh pengelola pesantren, bahwa dengan penerapan pendisiplinan dengan cara kekerasan ternyata tidak cukup untuk menghasilkan manusia yang baik, karena dengan kekerasan tersebut dapat membentuk karakter seseorang yang "sakit" secara psikis. Di samping itu, motivasi belajar yang terbentuk adalah motivasi yang ekstrinsik bukan motivasi yang intrinsik, motivasi ekstrinsik adalah motivasi yang terbentuk karena intimadasi dan kekerasan dan sifatnya tidak permanen, sementara motivasi intrinsik adalah motivasi yang terbentuk karena adanya proses pendekatan yang manusiawi dan sifatnya permanen. ${ }^{2}$ Motivasi yang terakhir ini memang kurang menjadi budaya di pesantren.

Tindakan kekerasan pada anak dalam pendidikaan di pesantren dapat dikategorikan dalam kekerasan fisik, psikis, seks, dan budaya. Kekerasan fisik dapat berupa hukuman penggundulan dan mengelilingi gedung bagi yang melanggar peraturan, berdiri di depan teman-temannya bagi santri yang tidak dapat menghafal tugas. Bentukbentuk kekerasan fisik tersebut merupakan suatu bentuk abuse, karena pada satu sisi kiai seharusnya melindungi tetapi pada kasus yang demikian kiai memberikan hukuman yang memungkinkan santri merasa malu dan akan berakibat minder kapada sesama temannya, bukankah hukuman yang lebih mendidik jauh lebih meaningfull dalam kehidupan mereka, dari pada hukuman fisik seperti di atas.

Sedangkan kekerasan psikis dapat digambarkan apabila terjadi jalinan asmara antara santriwan dan santriwati maka mereka dikeluarkan dari pesantren. Hukuman tersebut merupakan kekerasan psikis, karena menjalin asmara dengan lawan jenis merupakan fitrah bagi setiap individu, hukuman yang pantas dan layak untuk diberikan adalah tidak seberat hukuman di atas, karena mereka datang ke pesantren mempunyai niat untuk menuntut ilmu. Dengan penerapan hukuman tersebut di atas akan menghambat hak santri untuk mendapatkan pendidikan yang mereka kehendaki.

Kekerasan dalam kategori seks dapat digambarkan antara lain, apabila ditemukan santriwati yang cantik atau santriwan yang ganteng, maka mereka diambil sebagai menantu, meskipun para santri tersebut tidak menghendaki, akan tetapi pengasuh atau pihak kiai mengadakan berbagai macam pendekatan agar santriwati dan santriwan yang dikehendaki mau untuk menjadi menantu. Sedangkan kekerasan budaya dapat digambarkan apabila pihak pengasuh atau kiai melakukan tindak diskriminasi dalam pelayanan bagi santri yang berasal dari keluarga kiai dengan santri yang barasal dari keluarga petani. Hal tersebut semestinya tidak dilakukan mengingat dalam sistem

${ }^{1}$ Zaini Tamin AR, "Dinamika Perkembangan Kurikulum Pendidikan Pesantren; Satu Analisis Filosofis”, El-Banat: Jurnal Pemikiran dan Pendidikan Islam, Vol. 8, No. 1 (2018).

${ }^{2}$ Sardiman A.M, Interaksi dan Motivasi Belajar-Mengajar (Jakarta: Raja Grafindo Persada, 2007), 37. 
demokrasi pendidikan bahwa kesempatan mendapat pendidikan dan perlakuan pendidikan adalah sama dan tidak memandang status. Perlakuan yang diskriminatif tersebut akan dapat mengahambat terjadinya percepatan eksplorasi pembelajaran bagi santri yang berasal dari keluarga petani, dengan demikian potensi yang mereka miliki tidak dapat terekspose.

Berdasarkan pada contoh-contoh kasus di atas, pesantren sebagai sumber moral value, tentunya harus mereduksi tindakan-tindakan kekerasan dalam proses pendidikan yang mengatasnamakan pendisiplinan santri, karena pendidikan seharusnya dapat menyiapkan generasi yang mempunyai karakter yang self convidance. Karakter tersebut dibutuhkan dalam setiap kempetisi di kehidupan mereka. Oleh karena itu, pendidikan yang seharusnya diterapkan adalah pendidikan yang dilakukan dengan cara pendekatan yang humanis. Pendekatan ini berbicara soal bagaimana sebuah proses pendidikan harus dilihat pada faktor motivasi dan pengalaman emosional yang terbentuk dalam peristiwa belajar. $^{3}$

Sistem pendidikan pesantren - yang lebih mengutamakan pembinaan kepribadian daripada pengembangan intelektual - membuat daya kritis, semangat meneliti, dan reorientasi sebuah konsep keilmuan tidak berkembang. ${ }^{4} \mathrm{Hal}$ itu adalah bagian dari tradisi pesantren yang telah lama mengakar. Tentu menjadi diskursus yang sampai saat ini diperbincangkan. Pembinaan kepribadian tersebut berupa aturan ketat di mana aturan tersebut menjadi hukum di pesantren. Hukuman pada aturan tersebut dikenal dengan istilah ta'zir. Ta'zir diterapkan bagi santri melanggar peraturan di pesantren, baik dengan disuruh berdiri, menghafalkan ayat, digundul, dan lain sebagainya. Dilihat dari bentuknya, ta'zir di pesantren identik dengan kekerasan dalam pendidikan. Pembahasan tentang ta'zir semakin meruncing, tatkala dikaitkan dengan Hak Asasi Manusia (HAM). Tentu saja hal ini menjadi pukulan telak bagi pesantren yang sudah mengakar di Indonesia..

Penelitian ini menjadi penting untuk dilakukan dalam rangka mengetahui sejauh mana tindakan kekerasan anak dalam pendidikan di lembaga pesantren, dalam hal ini melalui $t a^{\prime} z i r$. Di samping itu, hal ini dapat menjadi pintu masuk terhadap penelitianpenelitian yang lain yang akan membidik cara solutif dalam mengurangi dan dapat dimungkinkan secara jangka panjang dapat menghilangkan bentuk-bentuk kekerasan dalam pondok pesantren. Hal demikian dapat dilakukan apabila sejumlah kalangan baik pengelola pesantren, orang tua, pemerintah dan tokoh pesantren memiliki pemahaman yang memadai tentang hak anak (santri) untuk mendapatkan hak pendidikannya dengan cara yang humanis.

Dalam Undang-Undang Republik Indonesia No. 23 tahun 2003 tentang perlindungan anak tertulis secara jelas bahwa, anak merupakan karunia Tuhan yang harus dijaga harkat, martabat dan hak-haknya sebagai manusia. Hak asasi anak merupakan bagian dari hak asasi manusia yang termuat dalam Undang-Undang Dasar 1945. ${ }^{5}$ Dengan demikian, anak didik harus dilindungi hak-haknya agar dapat menjadi generasi bangsa yang tumbuh dan berkembang guna kemajuan bangsa dan Negara.

\footnotetext{
${ }^{3}$ C. Asri Budiningsih, Belajar dan Pembelajaran (Jakarta: Rineka Cipta, 2005), 68.

${ }^{4}$ Imron Arifin, Kepemimpinan Kiai Kasus Pondok Tebu Ireng (Malang: Kalimasahada Press, 1993), 40.

5 Tim Permata Press, Undang-Undang Hak Asasi Manusia (Jakarta: Permata Press, 2012), 220.
} 


\section{Ta'zir; Antara Hukuman dan Pendisiplinan Santri di Pesantren}

Di pondok pesantren, Kyai menjadi central figure. Kiai bisa mengontrol penuh para santrinya, serta mengawasi perkembangan para santri khususnya di bidang keilmuan dan moral. Pondok pesantren merupakan fenomena sebagian gambaran kesederhanaan yang menjadi ciri khas kehidupan para santri. Meskipun seringkali terlihat sederhana, tidak beraturan, smrawut dan lain-lain, tetapi hal ini tidak mengurangi semangat para santri untuk mempelajari kitab kuning. ${ }^{6}$

Seperti kita ketahui, bahwa sumber identifikasi seorang anak tidak hanya kedua orangtuanya, tetapi bisa juga kepada figur-figur tertentu yang dianggap dekat dan memiliki pengaruh besar bagi anak. Keberadaan Kiai, pembimbing, ustad maupun teman sebaya juga bisa mempengaruhi pembentukan kepribadian anak melalui kedisiplinan. ${ }^{7}$ Dalam ilmu pendidikan, kedisiplinan dikenal sebagai cara menjaga kelangsungan kegiatan pendidikan. Metode ini identik dengan pemberian hukuma atau sangsi. Tujuannya untuk menumbuhkan kesadaran siswa bahwa apa yang dilakukan tersebut tidak benar, sehingga ia tidak mengulanginya lagi. ${ }^{8}$

Pembentukan lewat kedisiplinan ini memerlukan ketegasan dan kebijaksanaan. Ketegasan mengharuskan seorang pendidik memberikan sangsi bagi pelanggar, sementara kebijaksanaan mengharuskan sang pendidik sang pendidik berbuat adil dan arif dalam memberikan sanksi (dalam hal ini ta'zir ), tidak terbawa emosi atau dorongan lain. Dengan demikian sebelum menjatuhkan sangsi, seorang pendidik harus memperhatikan beberapa hal berikut :

Pertama, perlu adanya bukti yang kuat tentang adanya tindak pelanggaran. Kedua, hukuman harus bersifat mendidik, bukan sekedar memberi kepuasan atau balas dendam dari si pendidik. Ketiga, harus mempertimbangkan latar belakang dan kondisi siswa yang melanggar, misalnya frekuensinya pelanggaran, perbedaan jenis kelamin atau jenis pelanggaran disengaja atau tidak.

Ta'zir secara umum diberlakukan sebagai sanksi terhadap pelanggaran normanorma keagamaan, Pemidanaan dimaksudkan untuk mendatangakan kemaslahatan umat dan mencegah kezaliman atau kemadharatan. ${ }^{9}$ Sanksi ta'zir adalah suatu istilah untuk hukuman atas jarimah-jarimah yang hukumnya belum ditetapkan oleh syara', jadi istilah ta'zir bisa digunakan sebagai hukuman dan bisa juga untuk jarimah tindak pidana. ${ }^{10}$ Selain itu, harus dilihat juga apakah sistem yang ada telah menjamin pemenuhan kebutuhan paling mendasar manusia, misalnnya di masa khalifah Umar sebagai contoh, hukuman potong tangan pernah ditinggalkan karena terjadinya krisis kebutuhan pokok di masyarakat. Kalau hukuman itu diterapkan, justru tidak sesuai

6Yasmadi, Modernisasi Pesantren; Kritik Nurcholis Madjid terhadap pendidikan Islam Tradisional (Jakarta:Ciputat Press, 2002), 67.

${ }^{7}$ Lihat Djiwandono dan Sri Esthi Wuryani, Psikologi Pendidikan (Jakarta: Grasindo: 2002), 203.

${ }^{8}$ Hadari Nawawi, Pendidikan dalam Islam (Surabaya; Al-Ikhlas: 1993), 234

${ }^{9}$ Hasbi ash-Shiddieqy, Falsafah Hukum Islam (Jakarta: Bulan Bintang, 1975), 177.

10 Munajat, Fiqh Jinayah; Norma-Norma Hukum Pidana Islam, 158. 
dengan maqashid al-shari'ah ${ }^{11}$ atau tujuan hukumnya.

Ta'zir lebih bisa menjangkau dalam mengatur dan membatasi norma-norma Islam selalu terkait dengan norma-norma keimanan dan norma-norma moral serta menjadikan syariat Islam terhadap umatnya sebagai permasalahan akhlaq al-karimah, terlebih dalam upaya mendidik bagi santri sebagai cermin dalam kehidupan keberagamaan dan menanamkan kedisiplinan dalam kehidupan sehari-hari.

\section{Ta'zir vis a vis HAM}

Dalam ilmu pendidikan, kedisiplinan dikenal sebagai cara menjaga kelangsungan kegiatan pendidikan. Metode ini identik dengan pemberian hukuman. Tujuannya untuk menumbuhkan kesadaran siswa bahwa apa yang dilakukan tersebut tidak benar, sehingga ia tidak mengulanginya lagi. ${ }^{12}$ Sebelum menjatuhkan sangsi, seorang pendidik harus memperhatikan: perlu adanya bukti yang kuat tentang adanya tindak pelanggaran; hukuman harus bersifat mendidik, bukan sekedar memberi kepuasan atau balas dendam dari si pendidik; harus mempertimbangkan latar belakang dan kondisi siswa yang melanggar, misalnya frekuensinya pelanggaran, perbedaan jenis kelamin atau jenis pelanggaran disengaja atau tidak.

Hukuman diberikan selain sebagai pembuat jera bagi yang dihukum, juga sebagai upaya pencegahan. Hal itu pernah dijelaskan Emile Durkheim, bahwa hukuman merupakan suatu cara untuk mencegah berbagai pelanggaran terhadap aturan. Misalnya, guru menghukum muridnya agar murid tersebut tidak mengulangi kesalahannya, juga untuk mencegah agar murid-murid yang lain tidak melakukan hal serupa. ${ }^{13}$ Hukuman bertujuan untuk perbaikan kesalahan yang dilakukan seseorang serta memberi motivasi sebagai upaya edukasi. Ta'zir, dilakukan untuk memerikan peringatan serta upaya pencegahan dari berbagai pelanggaran.

Penelitian ini adalah bentuk kritik terhadap penerapan ta'zir di pesantren - yang beberapa penerapannya melanggar Hak Asasi Manusia. Penerapan tersebut, akan berimplikasi pada aspek psikologis dan fisik anak didik (santri). Maka penelitian ini meninjau penerapan ta'zir dari sudut pandang HAM. Sehingga temuan yang diharapkan akan memberi kontribusi positif bagi kalangan pesantren dalam hal pendidikan dan pendisiplinan santri. Dalam perspektif HAM, seluruh hak dan kebebasan yang dinikmati setiap individu tanpa memandang ras, warna kulit, jenis kelamin, bahasa, agama, opini politik, dan opini lainnya, asal-usul kebangsaan atau sosial, status kekayaan, kelahiran, dan status lainnya.

Nilai HAM di atas sangat universal dan baik. Harkat dan martabat manusia dijunjung tinggi terlepas dari perbedaan ras, agama, warna kulit, dan perbedaan lainnya. Dalam konteks ajaran Islam, nilai-nilai itu diakui sebagai sunnatullah. Di dalam Islam, menurut

${ }^{11}$ Maqa>s\}id al-shari>'ah merupakan tujuan umum perundang-undangan yang bertujuan untuk merealisasikan kemaslahan umum, memberikan kemanfaatan dan menghindari kemafsadatan bagi umat manusia. Mukhtar Yahaya dan Fathur Rahman, Dasar-dasar Pemahaman hukum Fiqh Islam,cet.III (Bandung: Al-Ma'arif,1993), 333.

12 Hadari Nawawi, Pendidikan dalam Islam (Surabaya; Al-Ikhlas: 1993), 234

${ }^{13}$ Emile Durkheim, Pendidikan Moral; Suatu Studi Teori dan Aplikasi Sosiologi Pendidikan (Jakarta: Erlangga, 1990), 116. 
Abu A'Ala Al-Maududi, ada dua konsep tentang Hak. Pertama, Hak Manusia atau huquq alinsan al-daruriyyah. Kedua, Hak Allah atau huquq Allah. Kedua jenis hak tersebut tidak bisa dipisahkan. Dan hal inilah yang membedakan antara konsep HAM menurut Islam dan HAM menurut perspektif Barat.

Egalitarianisme, demokrasi, persamaan hak di depan hukum, dan keadilan sosial, ekonomi, dan budaya mengejawantah dalam bentuk di antaranya dalam perbedaan dan keragaman dalam arti yang luas. ${ }^{14}$ Perbedaan, misalnya dalam pandangan Islam, adalah kehendak Allah karena itu segala upaya yang memaksa agar semua manusia itu seragam (satu agama, satu bangsa, satu warna kulit, satu opini politik) adalah penyangkalan terhadap sunnatullah itu. Dengan prinsip-prinsip yang sangat jelas di atas, maka setiap pemaksaan kehendak, penindasan, diskriminasi, intoleransi, terorisme, dan hal-hal yang menyalahi sunnatullah bukanlah ajaran Islam.

Penerapan ta'zir (hukuman) di pondok pesantren dapat dilaksanakan dengan syarat tidak melampui batas. Jika hukuman yang diberikan sudah melebihi batas (misalnya meninggal bekas pada tubuh santri) maka itulah yang dinamakan kekerasan terhadap santri. Oleh karena itu, penangan santri yang bermasalah harus dilakukan dengan baik dengan proses yang dan terstuktur yang sudah tertata rapi. Hal ini menghindari tindakan yang tidak proporsional kepada santri dengan prinsip-prinsip meletakkan persoalan dan pengangan sesuai dengan aturan yang berlaku. Dengan kata lain, hukuman itu diberikan untuk menekan, menghambat bahkan menghilangkan perbuatan yang menyimpang.

\section{Ta'zir di Pesantren Al Ibrohimy; Praktik, Problem dan Solusi \\ a. Penerapan Ta'zir di Pondok Pesantren Al Ibrohimy}

Di Pondok Pesantren Al Ibrohimy Galis Bangkalan misalnya, untuk membekali kemampuan dan pembentukan kepribadian santri, pihak pondok pesantren (pengasuh/kiai, pengurus pondok pesantren) memberikan pendidikan kepada santrinya dengan berbagai pola dan metode pembelajaran. Selain itu, pihak pondok pesantren melakukan pembinaan pendisiplinan kepada santri guna tercapainya tujuan pendidikan di lingkungan pesantren. Tindakan pendisiplinan tersebut berupa pemberian hukuman, misalnya gundul, menghatamkan Al-Qur'an dan lain sebagainya. ${ }^{15}$

Tindakan pendisiplinan kepada santri di Pondok Pesantren Al Ibrohimy Galis Bangkalan merupakan cara dalam pendisiplinan pengurus pondok terhadap santri yang bermasalah agar taat kepada peraturan-peraturan yang telah ditetapkan dan disepakati oleh pihak pengelola pengurus pondok pesantren. Penerapan hukuman juga dipahami sebagai sarana dalam mendidik santri agar menimbulkan efek jera dan tidak mengulanginya kembali.

Penerapan ta'zir (hukuman) di pondok pesantren ini diperlukan dan dilaksanakan dengan syarat tidak melampui batas. Jika hukuman yang diberikan sudah melebihi batas (misalnya meninggal bekas pada tubuh santri) maka itulah yang dinamakan kekerasan terhadap santri. Oleh karena itu, penangan santri yang bermasalah sudah dilakukan

14 Louise Marlow, Hierarchy and Egalitarianism in Islamic Thought (Cambridge: University of Cambridge Press, 1997), 15-17.

15 Hasil Observasi di Pondok Pesantren Al Ibrohimy, Galis, Bangkalan. 
dengan baik dengan proses yang dan terstuktur yang sudah tertata rapi. Hal ini menghindari tindakan yang tidak proporsional kepada santri dengan prinsip-prinsip meletakkan persoalan dan pengangan sesuai dengan aturan yang berlaku.

Hal ini diperjelas dengan hasil wawancara dengan Ustadz Mahasin, selaku ketua umum pengurus pondok pesantren Al Ibrohimy Galis Bangkalan, bahwa :

"Pendisiplinan kepada santri di pondok pesantren ini pada dasarnya memberikan penyadaran kepada santri yang bermasalah agar dia tidak mengulanginya lagi. Pondok pesantren ini sebenarnya bengkel terhadap anak yang bermasalah. Karena biasanya anak yang bermasalah rata-rata sudah mempunyai masalah sebelum mereka masuk kepadondok ini. Oleh karena itu pihak pondok pesantren tidak gegabah dalam menanganinya..."16

Pendapat di atas dipertegas oleh Koordinator Ketertiban Internal pesantren Al Ibrohimy, Ustadz Kholil Nurullah:

“...Berdasarkan data yang kami peroleh, Santri yang bermasalah di pondok ini sebenarnya mempunyai latar belakang masalah sebelum ia masuk kepondok ini misalnya: latar belakang keluarga, terutama anak dari blater/bajing, kondisi ekonomi, dan kurangya kasih sayang dari kedua orang tua dan lain sebagainya..."17

Dari uraian di atas, kita bisa melihat bahwa pemberian hukuman kepada santri bertujuan untuk mengarahkan atau menyadarkan atas kesalahan yang terlah dilakukan agar mereka tidak mengulanginya lagi. Menurut pengasuh pondok pesantren Al Ibrohimy, KH.Mas'udi Rifa'i, penerapan ta'zir di pesantren ini merupakan cara membentuk karakter santri dengan latar belakang yang beragam, baik sosial, budaya, ataupun lingkungan keluarga. ${ }^{18}$

“...Biasanya santri yang bermasalah, di rumahnya sudah bermasalah, hal ini karena orang tuanya sudah tidak mampu membimbingnya, lalu diserahkan kepada pondok pesantren. Menurut saya, pondok ini sebagai tempat perbaikan dan pembentukan akhlaq mereka. Kalau tidak bisa diperbaiki dan tidak mau dibentuk, maka akan dikembalikan kepada orang tuanya.."

Lebih lanjut menurutnya:

"Orang tua telah menyerahkan sepenuhnya kepada pesantren. Semisal, anak yang bermasalah dibina di sini. Mereka tidak keberatan jika anaknya dihukum. Di pondok ini ada lembaga bernama Bakortib (Badan Koordinasi Ketertiban Pesantren). Fungsi dari lembaga ini sebagai sarana ketertiban pesantren."

Dengan adanya lembaga tersebut, proses penganan santri bermasalah teratur sesuai dengan pelanggaran yang dilakukan. Berdasarkan uraian di atas, dapat diketahui bahwa Pondok Pesantren Al Ibrohimy Galis menggunakan ta'zir atau hukuman dalam mendidik para santrinya, $t a$ 'zir tersebut bertujuan untuk mendidik disiplin para santri. ${ }^{19}$

Dalam pemberian hukuman terhadap para santri dilakukan sesuai dengan prosedur yang telah ditentukan sesuai dengan tingkat kesalahan yang dilakukan. Ini dilakukan guna

16 Hasil wawancara dengan Ustadz Mahasin selaku ketua umum pengurus pondok pesantren $\mathrm{Al}$ Ibrohimy Galis Bangkalan, pada 20 Mei 2019.

17 Hasil wawancara dengan Ustadz Cholil Nurullah, selaku koordinator ketertiban internal pondok pesantren Al Ibrohimy Galis Bangkalan, pada 28 Mei 2019.

18 Hasil wawancara dengan KH.Mas'udi Rifa'i, selaku pengasuh pondok pesantren Al Ibrohimy Galis Bangkalan, pada Jum'at, 3 Mei 2019.

${ }^{19}$ Hasil observasi di Pondok Pesantren Al Ibrohimy Galis Bangkalan 
menghindari terjadi kekerasan dengan dalih mendidik disiplin pada santri. Selain itu juga bertujuan untuk menghindari pemberian hukuman yang subyektif pada santri yang melanggar terhadap peraturan, yang dapat memicu terjadinya kekerasan terhadap santri. Pemberian hukuman yang diberikan kepada santri selama ini tidak dianggap sebagai kekerasan karena masih sesuai dengan ketentuan dan tahapan-tahapan yang telah di tentukan oleh pondok pesantren.

Sebagaimana dijelaskan sebelumnya, maksud dan tujuan yang mendasar adanya ta'zir sebagai hukuman bagi santri yang melanggar aturan pondok pesantren lebih kepada upaya mendidik santri yang notabennya masih dalam masa pendidikan. Berdasarkan data yang ada di Pondok Pesantren Al Ibrohimy Galis, bentuk-bentuk ta'zir adalah sebagai berikut :20 (1) Baca Istighfar 1000 kali. Diterapkan bagi santri yang tidak ikut shalat berjamaah dan kegiatan Pondok Pesantren. (2) Membaca surat Yasin 20 kali, diberlakukan bagi santri yang tidak mengikuti kegiatan pondok sampai 3 kali. (3) Berdiri di halaman pondok pesantren dan membaca surat Yasin. Hukuman ini diperuntukkan bagi santri yang tidak mengikuti Madrasah Diniyah selama 1 pertemuan. (4) Gundul. Gundul diterapkan jika ada santri yang pulang tanpa pamit dan bagi santri yang berhubungan dengan bukan muhrim. (5) Menghatamkan al-Qur'an. Apabila ada santri yang tidak betah di Pondok, dan ingin boyong, maka diwajibkan menghatamkan alQur'an. (6) Pengembalian kepada wali santri (boyong). Boyong merupakan ta'zir atau sanksi yang paling berat. Sanksi ini diberikan kepada santri yang melakukan tindakan asusila dan kriminal.

Di atas merupakan hukuman-hukuman yang diberikan kepada para santri di Pondok Pesantren Al Ibrohimy Galis Bangkalan. Pemberian hukuman tersebut disesuaikan dengan tingkat kesalahan santri. Hukuman yang terendah diberikan membaca istighfar 1000 kali. Sedangkan hukuman tertinggi dilakukan dalam bentuk pemulangan atau pengembalian santri kepada orangtuanya. Ini biasanya dilakukan jika santri melakukan pelanggaran yang sangat besar dan berkali-kali.

Namun, sebelum keputusan pemulangan ini diambil, pihak pondok pesantren memproses anak tersebut di meja tahkim di depan para pengasuh, pengurus dan semua pembina pondok pesantren.

“..Hukuman boyong atau pemulangan santri merupakan hukuman terberat di pondok pesantren ini. Hukuman ini merupakan ganjaran bagi santri yang melakukan hubungan dengan bukan muhrim. Itu merupakan balasan setimpal bagi santri yang melakukan pelanggaran tersebut..."21

Sebagai lembaga pendidikan Islam, pondok pesantren ini diharapakan dapat memperbaiki akhlaq para santri dan membentuk karakter mereka. Sehingga ketika santri kembali ke masyarakat, ia dapat mengamalkan segala apa yang diperolehnya di pondok pesantren dan memberikan teladan yang baik bagi masyarakat sekitarnya. Jika santri dipulangkan, itu memiliki arti bahwa pondok pesantren tidak lagi mampu menjadi tempat pembentukan karakter, dimana menjadi satu-satunya tempat yang oleh masyarakat

20 Hasil dokumentasi di Pondok Pesantren Al Ibrohimy Galis Bangkalan

21 Hasil wawancara dengan Ustadz Abdul Hannan, selaku sekretaris umum pengurus pondok pesantren Al Ibrohimy Galis Bangkalan, pada 9 Mei 2019. 
dianggap mampu untuk membentengi santri dari perilaku-perilaku menyimpang yang dilarang oleh agama. Oleh karena itu tidak sewajarnya santri dikembalikan kepada orangtuanya yang sebelumnya memiliki harapan yang besar demi kebaikan anaknya.

Dan satu hal yang menjadi stressing di sini adalah bahwa bentuk-bentuk hukuman tersebut telah disosialisakan kepada para wali santri ketika pertama kali mengantarkan anaknya untuk mondok. Jadi dengan tetap dipondokkan anaknya, ini memiliki arti bahwa para wali santri setuju dengan peraturan dan ketentuan hukuman yang diterapkan di pondok pesantren ini.

\section{b. Ta'zir di Pesantren Al Ibrohimy dalam perspektif Hak Asasi Manusia}

HAM adalah hak-hak dasar yang dimiliki oleh manusia, sesuai dengan kodratnya. Dalam pandangan Jan Materson, komisi HAM PBB, bahwa HAM adalah hak-hak yang melekat pada setiap manusia, yang tanpanya manusia mustahil dapat hidup sebagai manusia. John Locke menyatakan bahwa HAM adalah hak-hak yang diberikan langsung oleh Tuhan Yang Maha Pencipta sebagai hak yang kodrati. ${ }^{22}$

Dalam pasal 1 Undang-Undang Nomor 39 Tahun 1999 tentang HAM disebutkan bahwa Hak Asasi Manusia adalah seperangkat hak yang melekat pada hakekat dan keberadaan manusia sebagai makhluk Tuhan Yang Maha Esa dan merupakan anugerahNya yang wajib dihormati, dijunjung tinggi, dan dilindungi oleh negara, hukum, pemerintah dan setiap orang, demi kehormatan serta perlindungan harkat dan martabat manusia.

Secara normatif, nilai-nilai HAM dirumuskan oleh PBB dalam sebuah deklarasi yang kemudian dikenal sebagai Deklarasi Hak Asasi Manusia Universal (Universal Declaration of Human Rights) PBB pada 10 Desember 1948. Deklarasi ini disepakati oleh 48 negara dimaksudkan untuk menjadi standar umum yang universal dari hak asasi manusia bagi sleuruh bangsa dan umat manusia. Deklarasi ini menyebutkan seluruh hak dan kebebasan yang dinikmati setiap individu tanpa memandang ras, warna kulit, jenis kelamin, bahasa, agama, opini politik, dan opini lainnya, asal-usul kebangsaan atau sosial, status kekayaan, kelahiran, dan status lainnya.

Islam adalah agama yang universal dan komprehensif yang melingkupi beberapa konsep. Konsep yang dimaksud yaitu aqidah, ibadah, dan muamalat yang masing-masing memuat ajaran keimanan. Aqidah, ibadah dan muamalat, di samping mengandung ajaran keimanan, juga mencakup dimensi ajaran agama Islam yang dilandasi oleh ketentuanketentuan berupa syariat atau fikih. Selanjutnya, di dalam Islam, ada dua konsep tentang Hak. Pertama, Hak Manusia atau huquq al-insan al-dharuriyyah. Kedua, Hak Allah atau huquq Allah. Kedua jenis hak tersebut tidak bisa dipisahkan. Dan hal inilah yang membedakan antara konsep HAM menurut Islam dan HAM menurut perspektif Barat.

Inti dari HAM adalah egalitarianisme, demokrasi, persamaan hak di depan hukum, dan keadilan sosial, ekonomi, dan budaya. Elemen-elemen itu mengejawantah dalam bentuk di antaranya dalam perbedaan dan keragaman dalam arti yang luas. ${ }^{23}$ Perbedaan,

22 Kaelan, Pendidikan Pancasila (Michigan: Michigan University Press, 2008), 140.

23 Louise Marlow, Hierarchy and Egalitarianism in Islamic Thought (Cambridge: Unibersity of Cambridge Press, 1997), 15-17. 
misalnya dalam pandangan Islam, adalah kehendak Allah karena itu segala upaya yang memaksa agar semua manusia itu seragam (satu agama, satu bangsa, satu warna kulit, satu opini politik) adalah penyangkalan terhadap sunnatullah itu.

Adanya ta'zir merupakan sanksi yang diterapkan sebagai ganjaran untuk santri yang melanggar aturan, dalam upanya pencegahan agar tidak terjadi pelanggaran yang sama. Penerapan ta'zir tentunya merupakan akibat dari perilaku santri yang tidak patuh terhadap apa yang ditetapkan di Pondok Pesantren ini. Namun, perlu digarisbawahi, bahwa santri sebagai anak mempunyai hak-hak yang harus diperhatikan dan dipenuhi. Mereka mempunyai hak asasi yang melekat sejak dilahirkan. Harkat dan martabat santri dijunjung tinggi terlepas dari perbedaan suku, warna kulit, psikologis, dan perbedaan lainnya. Dalam konteks ajaran Islam, nilai-nilai itu diakui sebagai sunnatullah.

Sementara itu, faktor-faktor diterapkannya ta'zir kepada para santri adalah sebagai berikut : ${ }^{24}$ Melanggar peraturan pondok pesantren adalah peratuan yang ditetapkan oleh pengasuh dan pengurus pondok pesantren (seperti: tidak sholat berjamaah, jika liburan pondok tidak kembali sesuai dengan waktu yang telah ditentukan, tidak ikut ngaji tanpa alasan yang jelas dan lain-lainnya), sering keluar malam melebihi ketentuan batasan pondok pesantren, keluar Tanpa Izin, dalam hal ini izin kepada pengurus yang merupakan representasi pengasuh, merokok, hal ini karena pondok pesantren merokok dipandang sebgai perbuatan makruh (perbuatan yang tidak ada gunanya dan lebih baik ditinggalkan), berhubungan selain muhrim (hubungan laki-laki dan perempuan yang bukan saudara dalam hal ini hubungan pacaran), penganiyaan (bertengkar) belajar mengajar, mencuri, dan lain sebagainya.

Hukuman yang diterima sesuai dengan tingkat kesalahan yang dilakukan santri. Penetapan hukuman tersebut dilakukan oleh badan keamaan pondok pesantren yang terdiri dari beberapa orang, yang sebelumnya telah dimusyawarahkan oleh para pengurus pondok pesantren Al Ibrohimy. Penerapan ta'zir dapat mencegah pelanggaran serupa terjadi lagi. Hal itu disebabkan karena santri yang melanggar, merasa malu, karena hukuman tersebut diketahui seluruh lapisan pondok pesantren, sebagaimana diungkapkan oleh salah seorang santri yang bernama Muhammad Mustofa:

"Saya jera dan tidak mengulanginya lagi. Saya juga malu, kepada teman-teman, para pengajar dan pengasuh pondok. Saya harap bisa memperbaiki kesalahan yang pernah saya perbuat..."25

Memang, pemberian hukuman kepada santri ditujukan untuk efek jera. Dan hukuman yang diberikan kepada santri membuat mereka tidak mengulangi lagi, meski terkadang ada efek lelah ketika menjalani hukuman. Sedangkan dampak secara psikis seperti rasa malu merupakan dampak psikis yang dapat melukai perasaan santri sehingga santri merasa trauma dan dapat mempengaruhi perkembangan psikis santri.

Pada saat yang sama, rasa trauma akan menyelimuti pikiran santri yang sedang menjalankan pendidikannya di pesantren. Beberapa santri ada yang berdiam diri di

${ }^{24}$ Hasil wawancara dengan Ustadz Cholil Nurullah, selaku Koordinator Ketertiban Internal pondok pesantren Al Ibrohimy Galis Bangkalan, 23 Mei 2019.

25 Hasil wawancara dengan Muhammad Mustofa, salah seorang santri di Pondok Pesantren Al Ibrohimy Galis Bangkalan, pada 29 Mei 2019.. 
kamar dengan menjalankan aturan-aturan pesantren, karena khawatir hukuman serupa akan diterapkan. Hal ini diuangkapkan oleh Rosyid:

"..Saya pernah dihukum berdiri di depan halaman pondok, karena tidak masuk madrasah. Waktu itu saya lupa jadwal, karena ada PR dari sekolah. Saya ketahuan pengurus, kemudian saya disuruh berdiri di halaman. Setelah itu saya sering di kamar dan saya juga rajin masuk madrasah. Saya takut dapat hukuman lagi.."26

Dengan beberapa hukuman di atas, pengurus beranggapan bahwa tujuannya tidak hanya untuk kedisiplinan santri, tetapi juga untuk pesantren. Sebagaimana dikatakan oleh Ustadz Mahasin:

"Pesantren Al Ibrohimy sebagai salah satu lembaga pendidikan Islam mempunyai peran yang tidak ringan dalam ikut serta menyiapkan generasi yang Islami. Pesantren harus dapat memproduk output yang siap kembali maka masyarakat dengan segala aturan di dalamnya."27

Dalam konteks perlindungan anak, hendaknya pesantren menerapkan institusi yang ramah anak (santri), karena salah satu garapan pesantren adalah memproduk pribadi-pribadi santri yang mempunyai ciri khas life space sendiri-sendiri berdasarkan karakteristik budaya keluarga dan lingkungannya di mana mereka tinggal. Maka, institusi ramah anak semestinya harus dikembangkan, karena tanpa adanya keseimbangan pendidikan agama secara normatif dan aplikatif, produk pesantren hanyalah akan mengeluarkan produk yang setengah-setengah, pendidikan agama secara normatif adalah pendidikan agama yang berciri khas pada nilai-nilai luhur Islam yang terkandung dalam al-Quran dan al-hadits. Sementara pendidikan Islam yang apilikatif adalah bagaimana guru dapat benar-benar dalam menjalankan fungsi, tugas, dan perannya berdasarkan pada kedua nilai di atas.

\section{c. Dampak Penerapan Ta'zir terhadap Perkembangan Santri di Pondok Pesantren Al Ibrohimy}

Jika penerapan ta'zir melebihi batas, maka yang terjadi adalah kekerasan terhadap anak (dalam hal ini santri). Akibat pendisiplinan yang berlebihan, sesungguhnya tidak hanya diderita langsung oleh korban, tetapi implikasi sosialnya tidak mustahil merambah ke berbagai tingkatan. Pada tingkat perorangan, pendisiplinan yang berlebihan dapat mengakibatkan gangguan pada aspek kelangsungan hidup, pertumbuhan, dan perkembangan anak. Akibat terhadap kelangsungan hidup anak adalah kecacatan fisik dan kematian. Kecacatan fisik dapat menyebabkan anak tergantung pada orang lain dalam aktivitas kesehariannya.

Pendisiplinan yang berlebihan pada anak juga dapat mengakibatkan gangguan terhadap perkembangan psikologis dan kecerdasan. Gangguan ini jika tidak ditangani akan menimbulkan penyimpangan kejiwaan dan kurang optimalnya pencapaian IQ sesuai dengan potensi yang yang dimilikinya. Penyimpangan kejiwaan yang berat mungkin lebih jelas penanganannya, tetapi mungkin akan sulit bagi orang awam untuk mendeteksi kelainan yang tidak kasat mata dan hanya menjadi trauma.

${ }^{26}$ Hasil wawancara dengan Rosyid, salah seorang santri di Pondok Pesantren Al Ibrohimy Galis Bangkalan, pada 14 Agustus 2019.

27 Hasil wawancara dengan Ustadz Mahasin selaku ketua umum pengurus pondok pesantren Al Ibrohimy Galis Bangkalan, pada 19 Agustus 2019. 
Lebih spesifik pendisiplinan yang berlebihan yang dilakukan oleh orang dewasa kepada anak akan menimbulkan beberapa dampak, diantaranya : pertama, dapat menyebabkan hormon stress tidak lagi responsif, sehingga perasaan anak itu tidak lagi peka. Nampaknya belum menjadi sebuah kebiasaan yang ada di Indonesia untuk membawa anak ke psikiater atau psikolog jika terjadi kemunduran konsentrasi atau kelainan tindakan anak. Kedua, anak pada saat anak menjadi dewasa, mereka menjadi orang tua yang kurang sehat secara psikis. Ketiga, dapat menurunkan tingkat kemampuan bersaing secara sehat di lingkungannya. ${ }^{14}$

Dari pendapat di atas, dapat ditarik benang merah bahwa pendisiplinan yang berlebihan pada masa anak menyebabkan anak berpotensi memiliki gangguan kepribadian ambang sehingga kelak anak juga berpotensi menderita depresi pada masa dewasanya. Di samping itu timbulnya gejala disosiasi termasuk amnesia terhadap ingatan-ingatan yang berkaitan dengan penganiayaannya.

Ibnu Khaldun, juga menjelaskan dalam kitab Muqaddimah-nya bahwa pendidikan anak yang disertai kekerasan dan pemaksaan yang dilakukan oleh para guru, penguasa atau pelayan, akan menyebabkan jiwa anak menjadi sempit, hilang semangat, menjadi pemalas, dan mendorongnya untuk berdusta dan berbuat curang karena takut akan akan terjadinya kekerasan (pemukulan) lagi terhadapnya. Selain itu, pendidikan dengan cara pemukulan berarti juga telah mengajari anak untuk berbuat kasar (kekerasan), pemaksaan dan penipuan. Hal ini akan menjadi kebiasaan baginya, maka akan rusaklah nilai-nilai kemanusiaannya. ${ }^{16}$

Oleh karena itu, wajib bagi seorang pendidik (orang tua dan guru/ustadz) untuk tidak memberikan macam-macam hukuman kepada anak, untuk menjaga kemuliaannya. Dan juga tidak memberikan hukuman kepada anak didik secara berlebihan, seperti mengumumkan kesalahannya. Karena sesungguhnya kepribadian dan kemuliaan anak wajib untuk selalu dijaga.

Penerapan lingkungan pendidikan yang ramah anak menjadi sebuah cita-cita yang belum banyak tercover di dalam pelaksanaan proses belajar-mengajar pada umumnya. Ta'zir yang diterapkan di pesantren Al Ibrohimy memang bertujuan untuk pendisiplinan santri. Namun, pendisiplinan yang berlebihan, misalnya dengan menjemur, mengatakan bodoh, berdiri di depan kelas, gundul dan lain sebagainya selain membuat santri jera dan tidak mengulangi hal yang sama, ternyata di sisi lain juga mempunyai dampak yang negatif terhadap santri. ${ }^{28}$

Anak sebagai figur manusia mempunyai life space (ruang kehidupan) yang berbeda satu dengan yang lainnya. Apabila anak terkoyak perasaannya maka akan sakit pula psikisnya. Dan sakit secara psikis inilah yang tidak diharapkan dalam proses pendidikan, karena dengan kondisi anak yang mempunyai penyakit secara psikis maka tidak akan dapat memproduk anak yang mempunyai pribadi tangguh, mandiri, bertanggungjawab, dan dapat survive di tengah kehidupan masyarakat.

14 Ibid., 146.

16 Jamal Abdurrahman, Kaifa Rabaahum an-Nabiy al-Amin, diterjemahkan oleh Ardianingsih dengan judul, Pendidikan ala kanjeng Nabi (Yogyakarta:Mitra Pustaka, 2003), 131-134.

${ }^{28}$ Hasil observasi di Pondok Pesantren Al Ibrohimy Galis Bangkalan 


\section{Alternatif Sistem Pendisiplinan Santri di Pondok Pesantren Al Ibrohimy}

Meskipun dikatakan ta'zir adalah metode yang efektif dalam proses pendisiplinan santri, namun hal itu tidak lantas dijadikan langkah utama dalam tindakan pendisiplinan tersebut. ${ }^{29}$ Terkadang tindakan tersebut justru menjadikan santri menjadi tertekan. Dan hal ini bertolak belakang dengan Hak Asasi Manusia (HAM) di Indonesia, seperti yang termaktub dalam Undang-undang tentang Perlindungan Anak di bawah ini:

Tabel. 1

Ta'zir Ditinjau dari Hak Asasi Manusia (Undang-undang Perlindungan Anak)

Analisis

\begin{tabular}{|c|c|c|}
\hline No & Ta'zir & $\begin{array}{c}\text { UU HAM } \\
\text { (Perlindungan Anak) }\end{array}$ \\
\hline 1 & $\begin{array}{l}\text { Wajib lapor kepada } \\
\text { pengurus bagi santri } \\
\text { yang ingin ke luar area } \\
\text { Pondok Pesantren }\end{array}$ & $\begin{array}{l}\text { Pasal 11. Setiap anak } \\
\text { berhak untuk beristirahat } \\
\text { dan memanfaatkan waktu } \\
\text { luang, bergaul dengan anak } \\
\text { yang sebaya, bermain, } \\
\text { berekreasi, dan berkreasi } \\
\text { sesuai dengan minat, bakat, } \\
\text { dan tingkat kecerdasannya } \\
\text { demi pengembangan diri. }\end{array}$ \\
\hline 2 & $\begin{array}{l}\text { Membaca Istighfar } \\
1000 \text { kali. Diterapkan } \\
\text { bagi santri yang tidak } \\
\text { ikut shalat berjamaah } \\
\text { dan kegiatan Pondok } \\
\text { Pesantren. }\end{array}$ & $\begin{array}{l}\text { Pasal 6. Setiap anak berhak } \\
\text { untuk beribadah menurut } \\
\text { agamanya, berpikir, dan } \\
\text { berekspresi sesuai dengan } \\
\text { tingkat kecerdasan dan } \\
\text { usianya, dalam bimbingan } \\
\text { orang tua. }\end{array}$ \\
\hline 3 & $\begin{array}{l}\text { Membaca surat Yasin } \\
20 \text { kali, diberlakukan } \\
\text { bagi santri yang tidak } \\
\text { mengikuti kegiatan } \\
\text { pondok sampai } 3 \text { kali. }\end{array}$ & $\begin{array}{l}\text { Pasal 6. Setiap anak berhak } \\
\text { untuk beribadah menurut } \\
\text { agamanya, berpikir, dan } \\
\text { berekspresi sesuai dengan } \\
\text { tingkat kecerdasan dan } \\
\text { usianya, dalam bimbingan } \\
\text { orang tua. }\end{array}$ \\
\hline
\end{tabular}

Wajib lapor bisa

diberlakukan kepada

seluruh santri, tanpa

terkecuali. Hal ini

diterapkan bukan

untuk membatasi

pergaulan dan proses

kreasi. Namun, lebih

kepada pencegahan dari pengaruh negatif lingkungan di luar.

Membaca istighfar diterapkan sebagai hukuman yang bersifat edukatif dan penyadaran santri akan kesalahannya.

Seperti membaca istighfar 1000 kali, membaca surat Yasin 20 kali merupakan ta'zir yang diterapkan sebagai hukuman yang bersifat edukatif dan penyadaran santri. Ta'zir ini bisa diberlakukan dengan catatan tidak dengan paksaan dan kekerasan fisik

4 Berdiri di halaman Pasal 4. Setiap anak berhak Berdiri di halaman pondok pesantren dan untuk dapat hidup, tumbuh, pondok merupakan 


\begin{tabular}{|c|c|c|c|}
\hline & $\begin{array}{l}\text { membaca surat Yasin. } \\
\text { Hukuman ini } \\
\text { diperuntukkan bagi } \\
\text { santri yang tidak } \\
\text { mengikuti Madrasah } \\
\text { Diniyah selama } 1 \\
\text { pertemuan. }\end{array}$ & 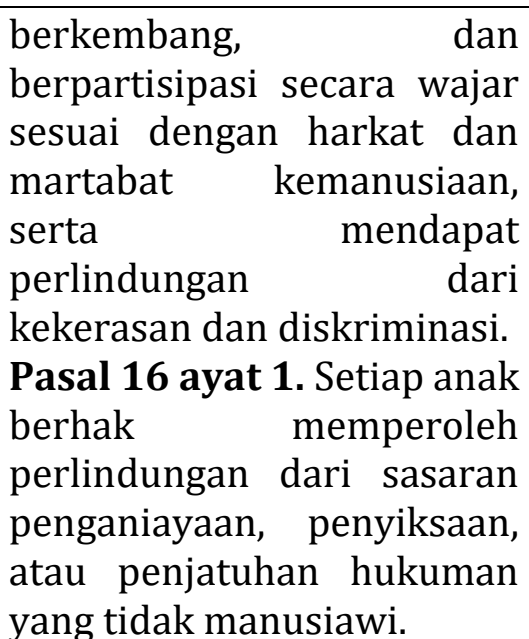 & $\begin{array}{l}\text { bentuk kekerasan } \\
\text { pendidikan yang tidak } \\
\text { hanya mencederai } \\
\text { fisik, tetapi juga psikis. } \\
\text { Karena selain santri } \\
\text { kepanasan dan lelah, } \\
\text { juga ada perasaan } \\
\text { malu kepada warga } \\
\text { pondok pesantren. Hal } \\
\text { ini jelas bertentangan } \\
\text { dengan Hak Asasi } \\
\text { Manusia }\end{array}$ \\
\hline 5 & $\begin{array}{lr}\text { Gundul. } & \text { Gundul } \\
\text { diterapkan jika ada } \\
\text { santri yang pulang } \\
\text { tanpa pamit dan bagi } \\
\text { santri yang } \\
\text { berhubungan dengan } \\
\text { bukan muhrim. }\end{array}$ & $\begin{array}{l}\text { Pasal 4. Setiap anak berhak } \\
\text { untuk dapat hidup, tumbuh, } \\
\text { berkembang, dan } \\
\text { berpartisipasi secara wajar } \\
\text { sesuai dengan harkat dan } \\
\text { martabat kemanusiaan, } \\
\text { serta mendapat } \\
\text { perlindungan dari } \\
\text { kekerasan dan diskriminasi. } \\
\text { Pasal 17 ayat 2. Setiap anak } \\
\text { yang menjadi korban atau } \\
\text { pelaku kekerasan seksual } \\
\text { atau yang berhadapan } \\
\text { dengan hukum berhak } \\
\text { dirahasiakan. }\end{array}$ & $\begin{array}{l}\text { Gundul memang tidak } \\
\text { terlalu berpengaruh } \\
\text { terhadap fisik santri. } \\
\text { Akan tetapi hal ini } \\
\text { merupakan pukulan } \\
\text { telak bagi psikis santri. } \\
\text { Karena ketika santri } \\
\text { digundul, maka akan } \\
\text { terjadi publikasi } \\
\text { berlebih tentang } \\
\text { pelanggarannya. Dan } \\
\text { hal ini merupakan } \\
\text { tindakan diskriminasi } \\
\text { terhadap santri } \\
\text { tersebut }\end{array}$ \\
\hline 6 & $\begin{array}{l}\text { Menghatamkan al- } \\
\text { Qur'an, bagi santri yang } \\
\text { tidak betah di Pondok, } \\
\text { dan ingin boyong, } \\
\text { maka diwajibkan } \\
\text { menghatamkan al- } \\
\text { Qur'an. }\end{array}$ & $\begin{array}{l}\text { Pasal 6. Setiap anak berhak } \\
\text { untuk beribadah menurut } \\
\text { agamanya, berpikir, dan } \\
\text { berekspresi sesuai dengan } \\
\text { tingkat kecerdasan dan } \\
\text { usianya, dalam bimbingan } \\
\text { orang tua. }\end{array}$ & $\begin{array}{l}\text { Seperti membaca } \\
\text { istighfar } 1000 \text { kali dan } \\
\text { membaca surat Yasin } \\
20 \text { kali, } \\
\text { menghatamkan al- } \\
\text { Qur'an merupakan } \\
\text { ta'zi>r yang } \\
\text { diterapkan sebagai } \\
\text { hukuman yang bersifat } \\
\text { edukatif dan } \\
\text { penyadaran santri } \\
\text { akan kesalahannya. }\end{array}$ \\
\hline 7 & $\begin{array}{l}\text { Pengembalian kepada } \\
\text { wali santri (boyong). } \\
\text { Boyong merupakan } \\
\text { ta'zi>r atau sanksi yang } \\
\text { paling berat. Sanksi ini } \\
\text { diberikan kepada } \\
\text { santri yang melakukan } \\
\text { tindakan asusila dan } \\
\text { kriminal. }\end{array}$ & $\begin{array}{l}\text { Pasal } 17 \text { ayat 2. Setiap anak } \\
\text { yang menjadi korban atau } \\
\text { pelaku kekerasan seksual } \\
\text { atau yang berhadapan } \\
\text { dengan hukum berhak } \\
\text { dirahasiakan. } \\
\text { Pasal } 9 \text { ayat 1. Setiap anak } \\
\text { berhak memperoleh } \\
\text { pendidikan dan pengajaran }\end{array}$ & $\begin{array}{l}\text { Dengan } \\
\text { mengembalikan santri } \\
\text { kepada orang tua, } \\
\text { Pesantren secara tidak } \\
\text { langsung melepas } \\
\text { tanggung jawabnya } \\
\text { untuk mendidik santri. } \\
\text { Padahal pesantren } \\
\text { merupakan salah satu }\end{array}$ \\
\hline
\end{tabular}




$\begin{array}{lrl}\text { dalam rangka } & \text { lembaga pendidikan } \\ \text { pengembangan pribadinya } & \text { yang } \\ \text { dan tingkat kecerdasannya } & \text { bertanggungjawab } \\ \text { sesuai dengan minat dan } & \text { untuk menjadi tempat } \\ \text { bakatnya. } & \text { mendidik, } \\ \text { Pasal 14. Setiap anak } & \text { membimbing dan } \\ \text { berhak untuk diasuh oleh } & \text { mengarahkan santri } \\ \text { orang tuanya sendiri, kecuali } & \text { untuk menjadi insa>n } \\ \text { jika ada alasan dan/atau } & \text { al-kami }>l \\ \text { aturan hukum yang sah } & \\ \text { menunjukkan bahwa } \\ \text { pemisahan itu adalah demi } \\ \text { kepentingan terbaik bagi } \\ \text { anak dan merupakan } \\ \text { pertimbangan terakhir. }\end{array}$

Berdasarkan tabel tersebut, pendisiplinan santri yang melebihi batas bertentangan dengan Undang-undang Hak Asasi Manusi (HAM). Pendisiplinan yang melebihi batas dengan dalih mendidik adalah sesuatu hal yang sulit untuk dihapuskan. Namun, hal ini tidak berarti bahwa frekuensi, prevalensi dan insidensi tindak kekerasan terhadap anak tidak dapat di reduksi atau diminimalisir. Oleh karena itu, harus segera ada langkah konkrit untuk menanggulangi/meminimalisirnya, yaitu:

Pertama, adanya payung hukum yang dapat memberikan perlindungan terhadap anak dari berbagai kekerasan dan kejahatan. Mengenai hal tersebut pemerintah telah membuat beberapa kebijakan, yaitu: (1) Pemerintah telah mengesahkan Undang-undang Nomor 23 tahun 2002 tentang Perlindungan anak, (2) dalam Keppres RI No. 88 Tahun 2002, tentang Rencana Aksi Nasional Penghapusan Perdagangan Perempuan dan Anak menyebutkan bahwa negara wajib melindungi dan menjaga kehormatan martabat bangsa, secara hukum, ekonomi, politik, sosial dan budaya tanpa membedakan suku, agama, ras dan golongan, (3) sebelum dilahirkannya UU No. 23 Tahun 2002, terdapat pula peraturan yang melindungi anak, antara lain UU No. 4/1979 tentang Kesejahteraan Anak, (4) Keppres No. 36/1990 tentang ratifikasi Konvensi Internasional Hak-hak Anak; UU No. 3/1997 tentang Pengadilan Anak; dan (5) UU No. 39/1999 tentang Hak Asasi Manusia, yang di dalamnya memuat HAM anak.

Kedua, membangun kesadaran dari pihak pesantren, wali santri dan masyarakat bahwa kekerasan terhadap santri (anak) adalah perbuatan yang tidak dapat dibenarkan dan diminta untuk segera melaporkan berbagai tindak kekerasan yang menimpa anak. Untuk mewujudkan hal tersebut ada beberapa hal yang harus dilakukan yaitu: (1), pemerintah harus mensosialisasikan undang-undang perlindungan anak baik di lingkungan pemerintah, aparat hukum maupun masyarakat. (2), pemerintah harus meningkatkan anggaran di sektor pendidikan sebagaimana diamanatkan oleh UUD 1945 sebesar 20 persen dan meningkatkan kualitas sekolah dengan kurikulum dan manajemen sekolah yang berpihak pada anak. (3), meningkatkan perlindungan hak azasi manusia dan menciptakan rasa aman kepada semua warga negara, terutama anak-anak. 
Meminimalisir ta'zir berlebih terhadap santri adalah tanggung jawab bersama yang melibatkan kemitraan antara pesantren, wali santri dan masyarakat luas. Ini berarti bahwa selain upaya yuridis yang diusulkan, keberhasilan dalam meminimalisir pendisiplinan berlebih terhadap anak semuanya berpulang pada masyarakat sendiri, yaitu sejauh mana masyarakat menyadari bahwa kekerasan terhadap anak dalam bentuk apapun dan dengan dalih apapun tidak dapat dibenarkan baik oleh Undang-undang terlebih lagi oleh agama.

Sedangkan terhadap santri yang telah dihukum (ta'zir) yang berlebihan, mereka harus segera diberikan pertolongan, agar dapat kembali menjalani kehidupan secara normal dan sehat, baik fisik maupun psikologis. Bantuan yang diberikan bisa bersifat preventif, kuratif, dan remidiatif. Bantuan kuratif dilakukan dengan cara menyebarluaskan pemahaman pada pihak pesantren, wali santri dan masyarakat, bahwa pendisiplinan yang berlebihan terhadap anak, baik karena emosi atau mendidik disiplin merupakan isu anak yang penting dan harus memperoleh perhatian yang serius, serta mencegah diri sendiri melakukan tindak kekerasan terhadap anak.

Selain langkah-langkah di atas, untuk meminimalisir pendisiplinan yang berlebihan terhadap anak, khususnya di pesantren, diperlukan suatu rekonstruksi sistem yang memberikan alternatif hukuman mendidik. Hukuman ini tentu mengikuti kaidah-kaidah yang telah ditentukan dalam shariat Islam. Sistem ini juga melibatkan masyarakat sebagai social control. Masyarakat dalam hal ini adalah penduduk sekitar pesantren, wali santri, dan media yang mempunyai perhatian terhadap kehidupan pesantren. Sudah saatnya pesantren menghidupkan kultur demokratis dalam pola pengajarannya dan memang sudah seharusnya pesantren memberikan pelajaran demokratis bagi santrinya, mengingat bangsa ini juga mulai menuju kehidupan yang demoktaris. Dan, perlu diberikan kebebasan pada santri untuk beraktualisasi dan mengekspresikan dirinya, mengingat hal ini penting untuk perkembangannya, karena pada hakikatnya santri merupakan representasi dari agent of social change di daerah asalnya.

\section{Kesimpulan}

Pondok Pesantren Al Ibrohimy Galis Bangkalan melakukan pembinaan pendisiplinan kepada santri guna tercapainya tujuan pendidikan di lingkungan pesantren. Tindakan pendisiplinan tersebut berupa pemberian hukuman ( ta $^{\prime} z i>r$ ), misalnya gundul, menghatamkan Al-Qur'an dan lain sebagainya. Tindakan pendisiplinan kepada santri di Al Ibrohimy Galis Bangkalan merupakan cara dalam pendisiplinan pengurus pondok terhadap santri yang bermasalah agar taat kepada peraturanperaturan yang telah ditetapkan dan disepakati oleh pihak pengasuh dan pengurus pondok pesantren. Penerapan hukuman juga dipahami sebagai sarana dalam mendidik santri agar menimbulkan efek jera dan tidak mengulanginya kembali. Ta'zir diangggap metode yang efektif dalam proses pendisiplinan santri. Namun, hal itu tidak lantas dijadikan langkah utama dalam tindakan pendisiplinan tersebut. Terkadang tindakan tersebut justru menjadikan santri menjadi tertekan. Dan hal ini bertolak belakang dengan Hak Asasi Manusia (HAM) di Indonesia, seperti yang termaktub dalam Undang-undang Hak Asasi Manusia tentang Perlindungan anak pasal 4, 6, 9 ayat 1,11, 16 ayat 1 dan pasal 
17 ayat 2. Oleh sebab itu, harus ada kesadaran pihak pesantren bahwa ta'zir yang berlebihan adalah perbuatan yang tidak sepenuhnya dapat dibenarkan. Maka, seluruh elemen pesantren harus memiliki opsi ta'zir yang tidak bertentangan dengan HAM. Selain itu, untuk meminimalisir ta'zir yang berlebihan, diperlukan suatu rekonstruksi sistem yang memberikan alternatif hukuman mendidik. Sehingga kegiatan pendidikan di pesantren berjalan secara dinamis dan humanis.

\section{DAFTAR PUSTAKA}

Abdurrahman, Jamal. Kaifa Rabaahum an-Nabiy al-Amin, diterjemahkan oleh Ardianingsih dengan judul, Pendidikan Ala Kanjeng Nabi. Yogyakarta: Mitra Pustaka, 2003.

Amir, Abd Aziz. al-Ta'zir fi al-Shari'at al-Islamiyyah. Mesir: Dar al-Bab al-Halabywa Awladuhu, t.t.

A.M, Sardiman. Interaksi dan Motivasi Belajar-Mengajar. Jakarta: Raja GrafindoPersada, 2007.

AR, Zaini Tamin. "Dinamika Perkembangan Kurikulum Pendidikan Pesantren; Satu Analisis Filosofis". El-Banat: Jurnal Pemikiran dan Pendidikan Islam, Vol. 8, No. 1 (2018).

Awdah, Abdul Qadir. al-Tashri' al-Jina'i al-Islamy.Kairo: Maktabah Arabah, 1963.

Bellah, Robert N. Beyond Belief. New York: Harper \& Row, Edisi Paperback, 1976.

Budaiwi, A. Ali. Imbalandan Hukuman dan Pengaruhnya bagi Pendidikan Anak. Jakarta: Gema Insani, 2002.

Daulay, Haidar Putra. Historitas dan Eksistensi Pesantren Pondok Pesantren dan Madrasah. Yogyakarta: Tiara Wacana, 2001.

Durkheim, Emile. Pendidikan Moral; Suatu Studi Teoridan Aplikasi Sosiologi Pendidikan. Jakarta: Erlangga, 1990.

Fananie, Husnan Bay. Modernism in Islamic Education in Indonesia and India ; A Case Study of The Pondok Pesantren Modern Gontor and Algarh, Thesis No Phublished. Nedherlad: Leiden University, 1998.

Farchan, Hamdan dan Syarifudin. Titik Tengkar Pesantren; Resolusi Konflik Masyarakat Pesantren. Yogyakarta: Pilar Media, 2005.

Haikal, Husein. Sirah Nabawiyah. Kairo: Maktabah al-'Arabiyah, 1960.

Hardiman, F. Budi. Hak-hak Asasi Manusia; Polemik dengan Kebudayaan dan Agama. Yogyakarta: Kanisius, 2011.

Kaelan. Pendidikan Pancasila. Michigan: Michigan University Press, 2008.

Khalifah, Izzat Iwadh. Kiat Mudah Mendidik Anak. Jakarta: Pustaka Qalami, 2004.

Khatib (al), Syarbini. Mughny al-Muhtaj. Mesir: Dar al-Bab al-Halabywa Awladuhu, 1958), 191.

Mahfudh, Sahal. Nuansa Fiqih Sosial. Yogyakarta: LKis, 1994.

Majid, Nurcholish. Bilik-Bilik Pesantren ; Suatu Potret Perjalanan. Jakarta: Paramadina, 1997. 
Marlow, Louise. Hierarchy and Egalitarianism in Islamic Thought. Cambridge: Unibersity of Cambridge Press, 1997.

Mas'ud, Abdurrahman. "Reward dan Punishment dalamPendidikan Islam", Jurnal Media. Edisi 28, Th.VI, November 1997.

Mazhariri, Husain. Pintar Mendidik Anak. tt: Lentera Basritama, 1999.

Monks, F.J. Psikologi Perkembangan Pengantar Dalam Berbagai Bagiannya. Yogjakarta : Gadjah Mada University Press, 2004.

Mubarok, Jaih. Kaidah-kaidah Fiqh Jināyah. Bandung: Pustaka Bani Quraisy, 2004.

Munajat, Makhrus. Fiqh Jinayah; Norma-Norma Hukum Pidana Islam. Yogyakarta: Syari'ah Press, 2008.

Muslih, Ahmad Wardih. Hukum Pidana Islam. Jakarta: Sinar Grafika, 2005.

Na'im (al), Abdullah Ahmed. Towards an Islamic Reformation: Civil Liberties, Human Rights and International Law. Syracuse: Syracuse University Press, 1990.

Simanjuntak, I.P. Perkembangan Pendidikan di Indonesia. Jakarta : Departemen Pendidikan dan Kebudayaan, 1973.

Steenbrink, Karel A., Pesantren Madrasah Sekolah; Pendidikan Islam Dalam Kurun Modern. Jakarta: LP3S, 1994.

Suyanto, Bagongdan Sri Sanituti Hariadi. Krisis \& Child Abuse (Kajian Sosiologis tentang Pelanggaran Hak Anak dan Anak-anak yang Membutuhkan Perlindungan Khusus/Children in Need of Special Protection). Surabaya: Airlangga University Press: 2002.

Syaltut, Mahmud. Islam Aqidah wa Shari'ah. Kairo: Dar al-Qalam, 1966.

Tim Permata Press. Undang-Undang Hak Asasi Manusia. Jakarta: Permata Press, 2012.

Unais, Ibrahim. al-Mu'jam al-Wasith. Mesir : Dar at-Turas al-Arabi, t.t.D.

UU 23/2002 tentang Perlindungan Anak Pasal 9.

Wahid, Abdurrahman. Pondok Pesantren Masa Depan. Bandung : Pustaka Hidayah, 1999.

Zaini, M. Fudholi., dkk,. Tarekat, Pesantren dan Budaya Lokal. Surabaya: Sunan Ampel Press, 1999.

Zuhaili (al), Wahbah. Haq al-Hurriyah Fi al 'Alam. Damshiq: Dar al-Fikr al Mu'assir, 2000. 